\title{
THE EFFECT OF SALIENCE AND DISPOSITION EFFECT ON STOCK INVESTMENT DECISIONS ON INVESTORS IN SURABAYA
}

\author{
Jessica Ratna Subandi ${ }^{1}$, Sautma Ronni Basana ${ }^{2}$ \\ 1,2 Finance and Investment Program \\ Faculty of Business and Economics, Petra Christian University \\ Jl. Siwalankerto 121-131, Surabaya \\ E-mail: 1jesicaratna@gmail.com; 2sautma@petra.ac.id
}

\begin{abstract}
This study aims to prove the effect of salience and disposition on investors' investment decisions in Surabaya. In addition, this study also seeks to see the effect of salience and disposition effect on investment decisions with the type of investor as a moderating variable. This type of research is quantitative research with associative methods and primary data sources. The data collection technique used a questionnaire. The data that has been collected is then processed using Partial Least Squares (PLS). The results showed that the salience and disposition effect had a significant influence on investment decisions. In addition, the types of investors weaken the relationship between the salience and disposition effect on investment decisions.
\end{abstract}

Keywords: Salience, disposition effect, behavior bias, investment decisions, investors.

\section{INTRODUCTION}

Investment is a postponement of consumption in the present to get higher profits in the future. (Bodie, Kane, \& Marcus, 2011). In choosing an investment decision, an investor must consider several factors. Some of them are the horizon investment and the needs of investors (Bodie, Kane, \& Marcus, 2011). When investors need investments to overcome short-term liabilities, investors invest in short-term investments. The actor of this investment is called the trader. Instead, investors engage in long-term investments to overcome their long-term liabilities. The actor of this investment is called the investor (Kapoor, Dlabay, \& Hughes, 2012).

When doing investment activities, an investor not only judges based on the fundamental analysis of a company but also sees based on the perceptions they build on a company or brand. (De Vries, Erasmus, \& Gerber, 2017). This statement is contrary to traditional financial theory which assumes that human behavior when making decisions is rational and financial market conditions are described as efficient markets (Yalcin, Tatoglu, \& Zaim, 2016). Behavioral finance appears to answer this phenomenon.

In behavioral finance, there are two groups of bias can cause investors to make irrational decisions, namely heuristics and prospect theory (Shefrin, 2018). Salience is a bias that belongs to the heuristic, while the disposition effect is a bias that belongs to the prospect theory. Salience is a condition in which investors make investment decisions based on familiarity or feeling close with the investment object (Chaudary, 2018). An example of salience behavior in Indonesia is shown in the case of PT Gudang Garam, where even though the cigarette excise price increased by $24.3 \%$ (Kementrian Kesehatan RI, 2018). However, GGRM's stock price rebounded in a relatively short period of time.

Meanwhile, the disposition effect is a condition in which investors tend to sell their shares when they are in a profit position and hold shares when they are in a loss position (Shefrin \& Statman, 1985). Investors tend to sell stocks when they are in a profitable position for fear that changes in market trends could reduce their profits (Gabriel \& Linawati, 2020). In addition, investors also hold their shares when they are at a loss for fear of regretting selling their shares. Investors also hope that stocks that decline will increase in the future. 
In this study, investors are divided into two types based on trading frequency. The first group is called traders. Individuals referred to as traders are those who buy and sell shares in a short period of time ( $\leq 1$ year). While individuals referred to as investors are those who hold an investment for an indefinite period of time or until the maturity date (Kapoor, Dlabay, \& Hughes, 2012).

Kumar \& Goyal (2015) emphasize that studies on bias caused by heuristics and prospect theory are still few in developing countries. Several studies have explained that heuristics can lead to biased behavior towards investment decisions in developing countries and developed countries. Based on the results of research and phenomena that occur, it is essential to conduct research that discusses salience and disposition effect on investment decisions of investors in Surabaya.

\section{LITERATURE REVIEW}

\section{Behavioral Finance}

Behavioral finance is a field of study that examines the causes of various irregularities in the market. This study departs from the assumption that the deviation of company stock prices is caused by investors who act irrationally (Barberis \& Thaler, 2002). This implies that an investor's investment decision is not based on a company's fundamental analysis but is based on investors' perceptions of a company or brand (De Vries, Erasmus, \& Gerber, 2017).

\section{Bounded Rationality Theory}

The theory of rationality is the behavioral finance first theory to challenge traditional financial theory. The bounded rationality theory refutes one of the basic propositions made in the traditional theory proposed by Adam Smith, namely that humans are economic humans (homo economicus) who are able to maximize utility and can make rational and optimal decisions from the possession of perfect information (Doucouliagos, 1994). Kamarck (2002) analyzed the causes of bounded rationality and found that humans can never make entirely rational decisions. This is due to various limitations, namely limited time, ability to think, and limited information. As a consequence of these actions, humans can only make decisions which merely satisfactory (satisficing).

\section{Prospect Theory}

Prospect Theory is a development of bounded rationality theory and first developed by Kahneman \& Tversky (1979). This theory illustrates that when a person is faced with two choices that can provide benefits, that person will be risk averse. The person will make the choice that gives a more definite advantage. However, when faced with two options that cause harm, that person will tend to be risk-seeking (Edwards, 1996).

\section{Salience Heuristic}

The heuristic is a way that can be called a shortcut used by someone to make decisions easily and quickly. Heuristics are also known as the rule of thumb, which is used for fast and efficient decision-making (Mishra, 2014). Tversky \& Kahneman (1979) stated that heuristics could also create bias, although heuristics can make decision-making faster. The bias caused by this heuristic can make decisions taken irrational. One of the factors that cause bias to arise in decision-making related to heuristics is salience.

Salience is a condition in which investors make investment decisions based on familiarity or close feeling with the investment object (Chaudary, 2018). Salience can also be referred to as familiarity bias (Yalcin, Tatoglu, \& Zaim, 2016) and breed investment familiarity (Huberman, 2001). When a person is faced with two risky choices, they feel more secure in choosing a familiar (salient), especially in decision making that demands speed (Fox \& Tversky, 1995). 


\section{Disposition Effect}

The disposition effect is a tendency where investors sell winning stocks too quickly and hold losers' stocks too long (Shefrin \& Statman, 1985). Shefrin and Statman (1985) develop four elements that make up the disposition effect: prospect theory, mental accounting, seeking pride and avoiding regret, and self-control.

\section{Investors}

When buying stocks, investing in stocks can be divided into short term and long term. Individuals who buy and sell stocks for a short period ( $\leq 1$ year) are called traders. Meanwhile, individuals who hold an investment for an unlimited period of time or up to maturity are called investors (Kapoor, Dlabay, \& Hughes, 2012). Investing are highly recommended for everyone, but trading activity are not recommended for everyone. When trading, a trader must face very uncertain market conditions and constantly adapt. This can cause emotional and financial stress. Therefore, it is important to understand the risks associated with trading before starting.

A good trader is shown by several characteristics. The first characteristic is that they must be able to make rational decisions and not let emotions to influence investment decisions. In addition, traders must have resilience and confidence in carrying out trading activities. A successful trader dares to take a profitable position, but when a loss occurs, the trader does not hesitate to take a reverse position. Not only that, but traders must also have discipline and benchmarks for entry and exit points in stock trading (Suresh, 2013).

Meanwhile, a good investor is indicated by several characteristics. The first characteristic is to start investing activities as early as possible. In addition, investors make investments regularly and consistently. Other characteristics include being unaffected by emotions, focusing on a long-term horizon, and monitoring investment assets as often as possible to anticipate changes in the situation (Suresh, 2013).

Research Hypothesis

$\mathrm{H} 1$ : Salience affects investment decisions significantly.

$\mathrm{H} 2$ : The disposition effect affects investment decisions significantly.

H3: Salience affects investment decisions significantly with the type of investor as a moderating variable.

H4: Disposition effect affects investment decisions significantly with the type of investor as a moderating variable.

\section{METHODOLOGY}

The type of research is a quantitative study with an associative method. This study aims to see the effect of salience and disposition effects on short-term and long-term investment decisions and to see whether the differences between institutional investors and individual investors can strengthen the relationship between salience and investment decisions with the type of investor as a moderating variable.

The population of this study is all stock market investors live in Surabaya. The sampling technique used was non-random sampling with purposive sampling technique, namely selecting samples with specific criteria (Anderson et al., 2018). The target of this research is stock investors. The sample taken shoud meets the following criteria:

1. Investing in the Indonesia Stock Exchange

2. Domiciled in Surabaya. 
Meanwhile, the sample size calculation technique used in this study is to use the Lemeshow formula. Based on the calculation of the Lemeshow formula, the number of samples specified is a minimum of 100 respondents.

\section{Data Collection Methods and Procedures}

The data collection method used in this research by distributing questionnaires. Previously, the researcher would conduct a pre-test questionnaire to determine whether the questions made were understandable and did not mislead the respondents. Furthermore, valid questionnaires will be distributed to respondents who meet the sample criteria. Respondents will respond through a Likert scale, from a scale of 1 to 5 . 1 indicates that the respondent strongly disagrees with the questionnaire statement, 5 indicates that the respondent strongly agrees with the questionnaire statement.

\section{Data Analysis Techniques}

First, the author distributes pre-test questionnaires to ten respondents who met the sample criteria to determine whether the statements that become indicators in the study can be understood and can represent research indicators. After that, the researchers conducted a descriptive analysis to find out the characteristics of the research data. Furthermore, the authors use the analytical approach of Structural Equation Modeling (SEM), because by using a path diagram, the researcher can enter all the observed variables in accordance with the related theoretical model. SEM is a multivariate analysis method used to test the relationship between variables simultaneously. The SEM model is formed from several dependent variables and independent variables in the form of a structures built on several indicators that are observed or measured directly.

This study uses SEM analysis in the form of Partial Least Square (PLS) with data processing assisted by SmartPLS application. There are two PLS analysis models, namely the inner model and the outer model. The outer model can also be called as outer relation or measurement model. The outer model is a specification of the relationship between variables and their indicators. This model defines a latent construct with its manifest variable. Meanwhile, the inner model (inner relation or structural model) specifies the relationship between hidden or latent variables, namely exogenous variables with endogenous variables (Ghozali, 2014).

\section{ANALYSIS AND DISCUSSION}

\section{Description of Research Objects}

The data in this study were obtained from 100 respondents who are stock investors domiciled in Surabaya. From the data collected, the male respondents in this study were $66 \%$ of the total number of research respondents. Meanwhile, female respondents were $34 \%$. From the respondents' profile data based on age, most respondents are 21-30 years old (63\%), followed by respondents aged $31-40$ years (19\%). The remaining respondents came from the $41-50$ age group $(10 \%)$, the $\leq 20$ years age group ( $5 \%$ ), and the $\geq 50$ age group. Based on education level, $55 \%$ of the total sample were respondents who had taken an undergraduate. In addition, $40 \%$ of the total sample are high school graduates. While the rest are graduates from postgraduate. There were no respondents who took doctoral/equivalent education in this study. Based on the respondent's occupation, $48 \%$ of the total sample of respondents have Student / Student status. $22 \%$ of the total sample are respondents who work in non-financial institutions, and $20 \%$ of the total sample are respondents who work in financial institutions. The rests are entrepreneurs (8\%) and retirees $(2 \%)$. Based on the respondent's income, $59 \%$ of the total respondents have an income below IDR $10,000,000$. $25 \%$ of the total respondents have an income ranging from IDR 10,000,001$20,000,000.13 \%$ of the total respondents have income ranging from IDR $20,000,001-30,000,000$ and the rest (3\%) have income above IDR 30,000,000. 


\section{Descriptive Answers of Respondents}

1. Descriptive Answers about Investment Decisions

Overall, the mean score of the investment decision is 4.16 , which means that stock investors in this study consider factors that can influence their investment decisions. The investment decision indicator that has the highest assessment of respondents has an average score of 4.61, which is about the respondent's portfolio, which focuses on several types of assets. In contrast, the investment decision indicator with the lowest assessment of respondents has an average score of 3.65 , which is about the frequency of respondents doing portfolio management at least twice a week. The description of the investment decision between a trader and an investor produces an average value of 4.27 and 4.08, respectively, this shows that the level of trader's investment decision is higher than that of an investor.

2. Descriptive Answers about Salience

The total mean score of respondents to the salience is 4.10 , which means that the respondents in this study tend to consider expert opinion and have preferences in making investment decisions. These preferences include shared personal values and a sense of closeness/familiarity with the issuers of stocks. The indicator salience with the highest value from the respondent is S.3 with an average of 4.37 , which is about the respondents' awareness of investing in a company that has a good reputation. In contrast, the indicator salience with the lowest value of the respondent is $S .5$ with an average of 3.63, which is about the respondent's desire to invest in companies whose products are preferred. The description of the variable salience between a trader and an investor produces an average value of 4.03 and 4.15, respectively. This shows the level of salience of an investor is higher than that of a trader.

3. Descriptive Answer about the Disposition Effect

The mean score of respondents' answers about disposition effect is 4.00 . This indicates that respondents in this study tend to agree with statements related to a person's behavior in dealing with risk, such as delaying the sale or losing shares for fear of regret. The indicator of disposition effect that has the highest assessment of respondents has an average score of 4.10, which is about the concern of respondents if shares that are experiencing profits are not immediately sold, it will experience a decrease in value and reduce profits. In contrast, the indicator of disposition effect which has the lowest rating from the respondents has an average score of 3.84, which is about the ease of selling stocks that have increased in value. The description of the disposition effect between a trader and an investor produces an average value of 3.78 and 4.17 , respectively. This shows that the level of the disposition effect of an investor is higher than that of a trader.

\section{Partial Least Square (PLS)}

This study uses the method partial least square to test the research hypothesis using SmartPLS software.

1. Outer Model

In the evaluation of the outer model of the study, there are three indicators to be tested, namely convergent validity, discriminant validity, and composite reliability. The research results show that the value outer loading for each indicator in the investment decision, salience, and disposition effect has a value of more than 0.50 . This means that the indicators in this study which are used to measure the investment decision, salience, and disposition effect have met the convergent validity. Based on the AVE value, it can be seen that the investment decision, salience, disposition effect has an AVE value above 0.5. Thus, the investment decision, salience, and disposition effect are said to have met discriminant validity.

Based on the research results, the composite reliability and Cronbach's alpha value of each research variable have more than 0.60 . Thus, it can be concluded that each of the investment decision, salience, and disposition effect has met composite reliability.

2. Inner Model

The first evaluation on the inner model is seen from the R-Square value or the coefficient of determination. Based on data processing with PLS, the resulting R-square value is $29.6 \%$. This value shows the percentage effect of salience and disposition effect on investment decisions is $29.6 \%$, while the remaining $70.4 \%$ is influenced by other variables. 
The following evaluation is hypothesis testing. In this study, the hypothesis testing was carried out twice, namely the main model hypothesis testing and hypothesis testing with a moderating effect. The following is the equation of the main research model:

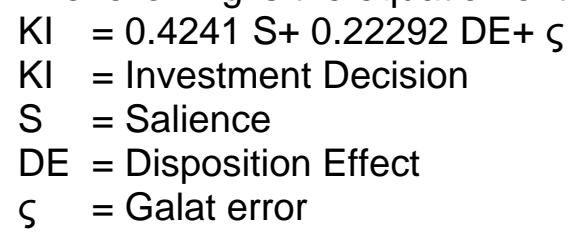

The coefficient value of the effect of salience on investment decisions is 0.424 with T-statistics of 3.678 (greater than the t-table value of 1.96) and p-value of 0.000 (less than $5 \%$ ); this shows that salience has a significant effect on investment decisions. Based on the regression results, the first hypothesis $\mathrm{H} 1$, salience, has a significant effect on investment decisions, is acceptable.

The coefficient value of the disposition effect on investment decisions is 0.229 with a T-statistics of 2.945 (greater than the t-table value of 1.96) and a p-value of 0.003 (less than $5 \%$ ). This shows that the disposition effect has significant effect on investment decisions. The higher the disposition effect, the more significant the impact on increasing investment decisions. Based on the regression results, the second hypothesis $\mathrm{H} 2$, disposition effect has a significant effect on investment decisions, is acceptable.

The hypothesis of the moderating effect of the investor type in the influence of the salience and disposition effect on investment decisions is tested using PLS analysis, which is to see the total effect on the bootstrapping process. The research hypothesis is accepted if the interaction effect results in a t-statistic value $\geq 1.96$ or the $p$-value is smaller than the error rate $(\alpha)$ of $5 \%$. The following is a research equation model with a moderating effect:

$\mathrm{KI}=-0.266\left(\mathrm{~S}^{*} \mathrm{TI}\right)-0.211\left(\mathrm{DE}{ }^{*} \mathrm{TI}\right)+\varsigma$

Information:

$\mathrm{KI} \quad=$ Investment Decision

$\mathrm{S} \quad=$ Salience

$\mathrm{DE} \quad=$ Disposition Effect

$\mathrm{TI} \quad=$ Investor Type

$\varsigma \quad=$ Galat error

The coefficient value of the interaction effect of salience* type of investor on investment decision is -0.266 (negative) with a T-statistics of 2.475 (greater than the t-table value of 1.96) and a $p$-value of 0.014 (less than $5 \%$ ). This shows a significant interaction effect, so it is concluded that the type of investor moderate's the effect of salience on investment decisions. The interaction coefficient is negative (-) indicating the type of investor weakens the effect of salience on investment decisions. This means that salience on traders is weaker than the effect of salience on investors on making investment decisions. Based on these results, the third hypothesis suspects that salience affects investment decisions on investors in Surabaya, with the type of investor as the moderating variable is accepted.

The coefficient value of the interaction disposition effect ${ }^{*}$ type of investor on investment decisions is -0.211 (negative) with a T-statistics of 2.570 (greater than the t-table value of 1.96) and a $p$ value of 0.010 (less than $5 \%$ ). This shows a significant interaction effect, so we can conclude that the type of investor also moderates the effect of the disposition effect on investment decisions. The interaction coefficient is negative (-), indicating the type of investor weakens the impact of the disposition effect on investment decisions. This means that the impact of the disposition effect on traders is weaker than the effect of the disposition effect on investors making investment decisions. Based on these results, the fourth hypothesis, which suspects that the disposition effect affects investment decisions on investors in Surabaya with the type of investor as the moderator variable, is acceptable. 


\section{Discussion}

Based on the research results, salience is proven to have a significant effect on investment decisions. These findings have supported the research of Sirri \& Tufano (1998) and Jain \& Wu (2000) where investors choose to invest in companies that are more prominent (familiar). The results of this study support Fox and Tversky (1995), who state that investors feel more comfortable choosing familiar issuers when faced with risky choices, as indicated by the mean score of 4.19 on the statement that it is very risky to invest in unknown companies. This is because stocks have a higher level of risk than fixed income securities such as bonds, so investors are more careful in investing in stocks.

The disposition effect is proven to influence investment decisions significantly. This supports research from Shefrin (1985) and Odean (1998a), which states that the disposition effect has a significant effect on investment decisions. This finding also supports the prospect theory proposed by Kahneman \& Tversky (1979), where when investors get capital gains, they will immediately realize the returns by selling shares and vice versa, tend to sell their shares quickly because they are worried that they will get capital loss if they are not immediately sold.

The results showed that salience (familiarity) significantly influence investment decisions with the type of investor as a moderating variable. The interaction coefficient results show a negative number, which means that the effect of salience on traders is weaker than the effect of salience on investors on investment decision making. The previous statement concluded that investors in this study have a stronger salience bias than traders. This finding supports the statement of Kourditis et al. (2011), which states that investors who are involved in long-term investment activities are more prone to behavior bias in the form of having a preference for well-known stocks. Chaudary (2018) also argues that long-term investors choose to invest in stocks known to increase investor confidence and increase investor expectations of higher returns.

The disposition effect affects investment decisions significantly with the type of investor as a moderating variable. The results of the interaction coefficient show a negative number, indicating that investors in this study experience a disposition effect more than traders. This is because a trader generally makes short-term transactions with high frequency. When a stock reaches the desired profit point, the trader does not hesitate to sell the stock. In addition, traders usually setpoints stop-loss so they don't hesitate to sell shares when they reach a predetermined point of loss. Meanwhile, investors who make long-term investments tend to be exposed to the disposition effect because they monitor stock price movements from time to time, thereby creating investor expectations of stock performance (Svedsater, Karlsson, \& Garling, 2009).

\section{CONCLUSIONS AND RECOMENDATION}

\section{Conclusion}

Based on the analysis and discussion that has been described, can be drawn the following conclusions:

1. Salience has a significant effect on investors' investment decisions in Surabaya.

2. The disposition effect has a significant effect on investors' investment decisions in Surabaya.

3. Salience has a significant effect on investor investment decisions in Surabaya, with the type of investor as a moderating variable.

4. The disposition effect has a significant effect on investor investment decisions in Surabaya, with the type of investor as a moderating variable.

\section{Recomendation}

Based on the results of the research and the conclusions drawn from this study, the following suggestions can be made by the next researcher, namely: 
1. Analyzing other behavioral biases such as herding behavior and availability bias greatly affects investors' investment decisions. In addition, this behavioral bias can make the stock price mispriced.

2. Analyzing the effect of salience and disposition effect on a broader research object, for example, investors in Indonesia. In addition, the research object can be generalized, such as focusing on stock investors. Further researchers can also analyze these behavioral biases on other securities investors such as bonds and other securities.

\section{REFERENCES}

Anderson, D. R., Sweeney, D. J., Williams, T. A., Camm, J. D., \& Cochran, J. J. (2018). Statistics for business \& economics. Cengage Learning.

Barberis, N., \& Thaler, R. (2002). A Survey of Behavioral Finance. doi:doi:10.3386/w9222

Barberis, N., \& Xiong, W. (2009). What Drives the Disposition Effect? An Analysis of A Long-standing Preference-based Explanation. The Journal of Finance, 751-784.

Bodie, Z., Kane, A., \& Marcus, A. J. (2011). Investments. New York: McGraw-Hill.

Chaudary, S. (2018). Does salience matter in investment decision? Differences between individual and professional investors. Kybernetes. http://doi.org/10.1108/K-09-2018-0490

De Vries, A., Erasmus, P. D., \& Gerber, C. (2017). The familiar versus the unfamiliar: familiarity bias amongst individual investors. Acta Comercii, 17(1), 1-10.

Doucouliagos, C. (1994). A Note on the Evolution of Homo Economicus. Journal of Economic Issues, 877883.

Edwards, K. D. (1996). Prospect theory: a literature review. International Review of Financial Analysis, 1938.

Fox, C. R., \& Tversky, A. (1995). Ambiguity aversion and comparative ignorance. The Quarterly Journal of Economics, 110(3), 585-603.

Gabriel, F., \& Linawati, N. (2020). Pengaruh financial capability, money attitudes, dan socioeconomic status terhadap adverse financial events. International Journal of Financial and Investment Studies (IJFIS), 1(1), 15-20. https://doi.org/10.9744/ijfis.1.1.15-20

Ghozali, I. (2014). Structural Equation Modeling: Metode alternatif dengan partial least square (PLS). Semarang: UNDIP.

Kahneman, D., \& Tversky, A. (1979). Prospect Theory: An Analysis of Decision under Risk. Econometrica, 47(2), 263. doi:10.2307/1914185

Kamarck, A. M. (2002). Economics as a social science: an approach to nonautistic theory. Ann Arbor: University of Michigan Press.

Kapoor, J., Dlabay, L. R., \& Hughes, R. J. (2012). Personal finance (10 ed.). New York: McGraw-Hill//rwin.

Kementrian Kesehatan RI. (2018). Profil Kesehatan Indonesia Tahun 2018. Jakarta: Kementrian Kesehatan Republik Indonesia.

Mishra, S. (2014). Decision-making under risk: Integrating perspectives from biology, economics, and psychology. Personality and Social Psychology Review, 18(3), 280-307.

Shefrin, H. (2018). Behavioral Corporate Finance. McGraw Hill Education.

Shefrin, H., \& Statman, M. (1985). The disposition to sell winners too early and ride losers too long: theory and evidence. Journal of Finance, 40, 777-790.

Suresh, A. (2013). Understanding Behavioral Finance Through Biases And Traits Of Trader Vis-À-Vis Investor. Journal of Finance, Accounting and Management.

Yalcin, K. C., Tatoglu, E., \& Zaim, S. (2016). Developing an instrument for measuring the effects of heuristics on investment decisions. Kybernetes, 45(7), 1052-1071. doi:doi:10.1108/k-05-2015-0130 